Brazilian Journal

of Chemical

ISSN 0104-6632

Engineering

\title{
BIOLEACHING OF METALS FROM A SPENT DIESEL HYDRODESULFURIZATION CATALYST EMPLOYING Acidithiobacillus thiooxidans FG-01
}

\author{
P. F. Ferreira ${ }^{1}$, E. F. C. Sérvulo ${ }^{1}$, A. C. A. da $\operatorname{Costa}^{2}$, D. M. Ferreira ${ }^{1}$, \\ M. L. D. P. Godoy ${ }^{3}$ and F. J. S. Oliveira ${ }^{4 *}$ \\ ${ }^{1}$ Universidade Federal do Rio de Janeiro, 21941-909, Rio de Janeiro - RJ, Brazil. \\ ${ }^{2}$ Universidade do Estado do Rio de Janeiro, 20550-900, Rio de Janeiro - RJ, Brazil. \\ ${ }^{3}$ Comissão Nacional de Energia Nuclear, 22780-160, Rio de Janeiro - RJ, Brasil. \\ ${ }^{4}$ Petróleo Brasileiro S.A., 20031-004, Rio de Janeiro - RJ, Brazil. \\ Phone: + 5521 32291372; Fax: + 552132291346 \\ *E-mail: f.oliveira@petrobras.com.br
}

(Submitted: April 4, 2015 ; Revised: October 13, 2015 ; Accepted: October 14, 2015)

\begin{abstract}
This study evaluates the recovery of heavy metals employing a spent catalyst from the hydrodesulfurization (HDS) of diesel, with no chemical, thermal or physical pretreatment, using the bacterial strain Acidithiobacillus thiooxidans FG-01. Direct and indirect bioleaching tests were carried out in Erlenmeyer flasks $(500 \mathrm{~mL})$. The influence of the pulp density and supplementation with elemental sulfur on the bioleaching were also investigated. The spent catalyst contained organochlorines, petroleum hydrocarbons and heavy metals in its composition. The best recovery results $(26 \% \mathrm{Al}, 26 \% \mathrm{~V}$ and $39 \% \mathrm{Mo})$ were achieved in the two-stage (indirect) bioprocess, with a pulp density of $50 \mathrm{~g} / \mathrm{L}$. It was not possible to recover $\mathrm{Co}, \mathrm{Cu}$ and $\mathrm{Ni}(<5 \%)$ under any of the conditions tested. The bacterial strain $A$. thiooxidans FG-01 was found to be a promising candidate for the recovery of Al, $\mathrm{V}$ and Mo using the crude spent HDS catalyst.

Keywords: Bioleaching; Spent hydrodesulfurization catalyst; Acidithiobacillus thiooxidans.
\end{abstract}

\section{INTRODUCTION}

A petroleum refinery is comprised of a set of units carrying out physical, chemical and thermal processes which are aimed at the separation of the crude oil components into fractions of hydrocarbon mixtures (Gary et al., 2007). Catalysis is an essential process employed at petroleum refineries to obtain gasoline, diesel and kerosene (aviation fuel). During the operations the catalysts become impregnated with impurities and are deactivated. After the deactivation the catalysts are sent to on-site or off-site regeneration units. With the continual processing of loads the catalysts become impregnated with coke, nickel, vanadium, sulfur, toxic hydrocarbons and other impurities to such a level that their regeneration becomes impracticable. At this stage the catalysts are referred to as 'spent' (Marafi and Stanislaus, 2008).

Considering that the global energy matrix is highly dependent on fossil fuels and given the many uses of catalysts in petroleum refining, vast amounts of spent catalysts are generated, with around 150,000 to 170,000 tonnes being produced per year (Marafi and Stanislaus, 2008). The hydroprocessing catalysts differ from all other types of spent catalysts generated at petroleum refineries since they contain heavy metals and other toxic substances (Jadhav and Hocheng, 2012). Due to the reactivity of these solid residues with atmospheric air and with water, together with

*To whom correspondence should be addressed 
the presence of heavy metals, hydrocarbons and other toxic chemicals, these materials are hazardous (Noori Felegri et al., 2014).

Besides the environmental issues, there is concern at the economic-strategic level, considering that the content of valuable heavy metals in spent catalysts is often higher than that found in natural sources (ores). Thus, the recovery of metals from spent catalysts can ensure the supply of metals of commercial value and consequently reduce the dependency on external suppliers and the degradation of new areas through mining activities. Therefore, besides being economically advantageous, the recovery of metals from spent catalysts also lies within the concept of sustainable development (Thosar et al., 2014).

Many researches have indicated that chemical leaching (employing inorganic and organic acids) and bioleaching are promising alternatives for the recovery of metals (Asghari et al., 2013; Jadhav and Hocheng, 2012; Marafi and Stanislaus, 2011). In contrast to chemical processes, biotechnological processes do not require high temperatures and pressures and they can therefore be more economically attractive. In this regard, several species of microorganisms which produce acids have been studied as heavy metal leaching agents, the most cited being of the genera Acidithiobacillus and Aspergillus (Thosar et al., 2014; Asghari et al., 2013; Bharadwaj and Ting, 2013; Mishra et al., 2008, Mishra et al., 2007). Recent publications in the literature report the microbial recovery of metals contained in spent catalysts from petroleum refining, pretreated through washing with solvents, thermal treatment and grinding or sieving (Srichandan et al., 2014a, Thosar et al., 2014; Noori Felegri et al., 2014; Bharadwaj and Ting, 2013). However, pretreatment operations can increase the costs associated with the bioleaching process on an industrial scale. Environmental and economic considerations motivated the carrying out of this innovative research, the objective of which was to verify the efficacy of the bacterial strain Acidithiobacillus thiooxidans FG-01 in the leaching of heavy metals from a crude spent HDS catalyst, that is, with no chemical, thermal or physical pretreatment.

\section{MATERIALS AND METHODS}

\section{Characterization of Hydrodesulfurization Catalyst}

The spent HDS catalyst, generated at a diesel treatment unit, was obtained from a petroleum refinery which processes heavy oils in Brazil. A plastic bag containing $200 \mathrm{~kg}$ of the solid waste (spent cata- lyst) was received from the refinery and samples were obtained using a stainless steel grain sampler, according to the procedures described by USEPA, (1980). Five kilograms of solid waste was subsampled by coning and quartering (USEPA, 1995) in a laminar flow cabinet, using a sterile scoop, and stored in sterile flakes prior to the bioleaching tests and analyses. Organic and inorganic determinations were chosen taking into account the waste generation source and the typical composition of HDS catalyst support (Beolchini et al., 2010).

Aliquots $(100.0 \mathrm{mg})$ of the spent catalyst, $4.0 \mathrm{~mL}$ of nitric acid, $2.0 \mathrm{~mL}$ of hydrochloric acid and 2.0 $\mathrm{mL}$ of hydrogen peroxide were placed in Teflon vessels. A microbalance (Mettler) was used to obtain the mass measurements for all samples. The sample digestions were carried out in a microwave oven (Ethos Plus, Milestone) equipped with an evaporation accessory (VAC 1000, Milestone). The temperature program was carried out in the following steps: 1) heating from $25^{\circ} \mathrm{C}$ to $140{ }^{\circ} \mathrm{C}(5 \mathrm{~min})$; 2) heating, from $140{ }^{\circ} \mathrm{C}$ to $\left.210^{\circ} \mathrm{C}(5 \mathrm{~min}) ; 3\right)$ Plateau, $210{ }^{\circ} \mathrm{C}$ (15 min) and, finally 4) ventilation for cooling down to $25{ }^{\circ} \mathrm{C}(15 \mathrm{~min})$. The potency of the microwave oven for following the temperature program varied from 400 to $850 \mathrm{~W}$. The acid-digested samples obtained were analyzed to determine the chemical elements composition using atomic absorption spectrometry (AAS) on a Perkin-Elmer spectrometer (AAnalyst 300).

Samples of the spent catalyst $(1 \mathrm{~g})$ were submitted to ultrasonic extraction with ultrapure dichloromethane and cleaned by silica gel column chromatography prior to the determination of organic substances. The concentrations of total hydrocarbons were determined by gas chromatography using a Thermo Finnigan Focus GC gas chromatograph, equipped with a column and a flame ionization detector (FID). The chlorinated organic compounds were quantified using the same instrument, equipped with a column and an electron capture detector. Polycyclic aromatic hydrocarbons (PAHs), benzene, xylenes and ethylbenzene were quantified by gas chromatography coupled to mass spectrometry, using a Thermo Finnigan, Focus GC / Themo Finnigan, Focus DSQ.

\section{Scanning Electron Microscopy (SEM) and Energy Dispersive X-Ray Spectroscopy (EDS)}

The catalyst samples were submitted to EDS and SEM analysis before and after the chemical and microbial leaching. These tests were carried out to examine the chemical composition and surface aspect 
of the HDS spent catalyst before and after the chemical or microbiological leaching tests. Prior to the microscopic analysis the samples were dried in an oven at $37{ }^{\circ} \mathrm{C}$ and then coated with silver. The observation of the catalyst particles was carried out with the aid of a scanning electron microscope (Zeiss DSM 940) equipped with an EDX Link detector and a Kontron (Zeiss) automatic image analysis system, under the following conditions: high voltage $=25$ $\mathrm{kV}$, secondary electrons mode, working distance $=$ $12.4-13.0 \mathrm{~mm}$. The chemical analysis was carried out by EDS (Oxford Link L300), with an SiLi Pentafet detector and an ultrafine window (ATW2), with $45 \mathrm{cps} / \mathrm{eV}$ (y axis) x $18 \mathrm{KeV}$ (x axis) of resolution, coupled to SEM.

\section{Bioleaching Tests}

The bioleaching tests were conducted using the bacterial strain Acidithiobacillus thiooxidans FG-01, kindly donated by the Institute of Chemistry at the State University of São Paulo (GARCIA Jr., 1991). The bacterial sample was isolated from an uranium mine in the state of Paraná, Brazil.

The bacterial strain was stored in T\&K liquid medium (Tuovinen and Kelly, 1973). The stock cultures were maintained at a temperature of $5 \pm 1{ }^{\circ} \mathrm{C}$, with subculturing every two months. The inoculums were prepared through the activation and propagation of $10 \mathrm{~mL}$ of the stock culture in $100 \mathrm{~mL}$ of T\&K medium, corresponding to an inoculum of $9.1 \%$ $(\mathrm{v} / \mathrm{v})$. The cultures were then incubated at $30 \pm 1{ }^{\circ} \mathrm{C}$, under shaking at $150 \mathrm{rpm}$ to provide the microorganisms with dissolved oxygen and thus accelerate their propagation. After 4 days of growth the cultures were submitted to verification of the purity by microscopic analysis (optical microscope, Olympus, model CX 40). The cellular concentration was determined using a Neubauer camera (Plumb et al., 2008; Mousavi et al., 2008), immediately prior to the bioleaching studies, to establish an initial concentration of $10^{5}$ cells $/ \mathrm{mL}$.

For the culture, the liquid media used were modified Deutsche Sammlung von Mikroorganismen und Zellkulturen - DSMZ (Silverman and Lundgren, 1959; Moura et al., 2008) and T\&K. These media were selected considering the claims of Kim et al. (2009) and Garcia Jr (1991) of successful microbial growth and sulfuric acid production. The $\mathrm{pH}$ value of the medium was adjusted to 2 using $0.5 \mathrm{~mol} / \mathrm{L}$ $\mathrm{H}_{2} \mathrm{SO}_{4}$, and $100 \mathrm{~mL}$ aliquots were placed in $500 \mathrm{~mL}$ Erlenmeyer flasks. The media were sterilized at 121 ${ }^{\circ} \mathrm{C}$ for $20 \mathrm{~min}$ and then supplemented with elemental sulfur $\left(\mathrm{S}^{\circ}\right)$, previously treated at $110^{\circ} \mathrm{C} / 60 \mathrm{~min}$, to obtain a concentration of $10 \mathrm{~g} / \mathrm{L}$. The bioleaching tests were carried out in $500 \mathrm{~mL}$ Erlenmeyer flasks containing $100 \mathrm{~mL}$ of medium and the selected amount of the spent catalyst. The flasks were shaken on a thermostatic incubator table (CIENTEC, model CT-712R), at $29 \pm 1{ }^{\circ} \mathrm{C}$ and $150 \mathrm{rpm}$, for different periods of time according to the test carried out. The concentrations of $\mathrm{Al}, \mathrm{Co}, \mathrm{Cu}, \mathrm{Mo}, \mathrm{Ni}$ and $\mathrm{V}$ in the solutions, the cell concentration, the $\mathrm{pH}$ and the acidity (expressed as sulfuric acid) were monitored. Aliquots $(25 \mathrm{~mL})$ of the suspension were removed from the flasks and filtered through polyacetate membranes (Millipore, $0.22 \mu \mathrm{m}$ ) prior to analysis. Abiotic controls were prepared by autoclaving the systems under a pressure of $1 \mathrm{~atm}$ for $20 \mathrm{~min}$. (Bharadwaj and Ting, 2013). Samples of abiotic controls were periodically examined for acid production and by light microscopy to verify microbial activity. To determine the $\mathrm{pH}$ a potentiometer (Digimed, model DMPH-1) equipped with a glass combination electrode (platinum working electrode and $\mathrm{Ag}^{\mathrm{O}} / \mathrm{AgCl}$ reference electrode) was used. Before each $\mathrm{pH}$ reading, and prior to the calibration with buffer solutions, the electrodes were immersed in a $5 \%(\mathrm{v} / \mathrm{v})$ formaldehyde solution for a period of $30 \mathrm{~min}$ for decontamination purposes. The acidity values for the samples of the medium were determined by titration with 0.1 $\mathrm{mol} / \mathrm{L} \mathrm{NaOH}$, using $0.1 \mathrm{~mL}$ of phenolphthalein as an indicator. The metal concentrations were determined by AAS (Perkin-Elmer, model AAnalyst 300).

\section{Effect of the Pulp Density}

The bioleaching texts were carried out under the above-described conditions, with different concentrations of spent catalyst: $5,10,25$ and $50 \mathrm{~g} / \mathrm{L}$. The tests were conducted over 7 days. Each test was carried out with at least three replicates and the results were presented as the mean value for the replicates. The process was monitored by sacrificing replicate flasks.

\section{Bioleaching in One or Two Stages}

In the one-stage process the growth of $A$. thiooxidans FG-01 and the solubilization of the metals were established concomitantly, using $500 \mathrm{~mL}$ Erlenmeyer flasks containing $100 \mathrm{~mL}$ of the T\&K liquid medium, $1 \mathrm{~g}$ of elemental sulfur and $0.5 \mathrm{~g}$ of spent catalyst. The $\mathrm{pH}$ was adjusted to 2 with the use of a solution of $1 \mathrm{~N} \mathrm{H}_{2} \mathrm{SO}_{4}$. In the two-stage process, only the catalyst was placed in the flask after cell growth had occurred, that is, when the maximum sulfuric acid concentration (40 g/L) had been reached. To the 
diluted leaching solutions appropriate quantities of the catalyst to establish a pulp density of $5,10,25$ or $50 \mathrm{~g} / \mathrm{L}$ were added. To allow comparisons, control tests were carried out for each acid concentration, where a commercial sulfuric acid solution was added in a concentration equal to that established for the acid produced by the bacteria. Abiotic controls were prepared by autoclaving the systems under a pressure of $1 \mathrm{~atm}$ for $20 \mathrm{~min}$. (Bharadwaj and Ting, 2013). Samples of abiotic controls were periodically examined for acid production (near to $0 \mathrm{mg} / \mathrm{L}$ ) and by light microscopy to ensure that there was no microbial activity. Each test was carried out with at least three replicates and the results were presented as the mean of the replicates. To monitor the bioprocess, replicate flasks were sacrificed periodically during the test.

\section{Statistical Analysis}

The results for the average metal recovery obtained in the indirect bioleaching tests, as a function of the pulp density of the crude spent catalyst, were submitted to analysis of variance (ANOVA) and multiple comparison of means (Tukey Test), under a completely randomized design, at the $5 \%$ significance level. In all cases, the analyses were carried out with the aid of the computational software program Statistica, version 5.5 (StatsoftInc).

\section{RESULTS AND DISCUSSION}

Petroleum refineries use different types of catalysts for the desulfurization of fuels (Dhar et al., 2003). In this regard, NiMo and CoMo-supported catalysts are the most commonly used types due to their activity and commercial interest. Table 1 shows the chemical characterization of the spent $\mathrm{CoMo} /$ $\mathrm{Al}_{2} \mathrm{O}_{3}$ catalyst. All results are expressed as the mean of three replicates. The presence of high concentrations of $\mathrm{Al}, \mathrm{Co}$ and $\mathrm{Mo}$ in the catalyst is due to its chemical composition, since it is comprised of an alumina support. Benzene and toluene were present in the samples in concentrations below the limit of detection (LOD; $521 \mu \mathrm{g} / \mathrm{kg}$ ).

\section{Microbial Growth and Acid Production}

Figure 1A shows the profiles for the growth and sulfuric acid production of the $A$. thiooxidans FG-01 bacteria in the two mineral media tested. It was noted that, with the use of the DSMZ medium, the bacterial strain showed a higher specific growth rate, reaching a maximum concentration $\left(3.0 \times 10^{7}\right.$ cells $\left./ \mathrm{mL}\right)$ on the fourth day of cultivation. A similar cell concentration was obtained with the growth in the T\&K medium, although a longer time period was required (five days of cultivation). The behavior of the bacterial strain was also distinct in relation to the production of acid, showing approximately linear and exponential profiles in the DSMZ and T\&K media, respectively. However, regardless of the composition of the medium, the yield and productivity of the process were similar, reaching maximum sulfuric acid concentrations of around $40 \mathrm{~g} / \mathrm{L}$. During the bacterial cultivation in modified DSMZ medium, inorganic acid was still produced, even after the maximum cell concentration had been reached (Figure 1A). Thus, in this medium the acid production was partially associated with the synthesis of cellular material. However, microbial growth and acid production

Table 1: Composition of spent hydrodesulfurization catalyst originating from a petroleum refinery.

\begin{tabular}{|c|c|c|c|}
\hline Parameter & $\begin{array}{c}\text { Result } \\
\text { (mg/kg) }\end{array}$ & Parameter & $\begin{array}{c}\text { Result } \\
(\mu g / k g)\end{array}$ \\
\hline Mercury & $0.2 \pm 0.1$ & 2,4,5-Trichlorophenol & $9727 \pm 1742$ \\
\hline Aluminum & $21615 \pm 1743$ & 2,4,6-Trichlorophenol & $10190 \pm 1659$ \\
\hline Arsenic & $91 \pm 5$ & 2,3,4,5-Tetrachlorophenol & $5258 \pm 1004$ \\
\hline Barium & $4 \pm 1$ & 2,3,4,6-Tetrachlorofenol & $<502$ \\
\hline Lead & $120 \pm 4$ & Anthracene & $2374 \pm 685$ \\
\hline Cobalt & $9715 \pm 837$ & Benzo(a)anthracene & $852 \pm 232$ \\
\hline Copper & $557 \pm 42$ & Benzo(k)fluoranthene & $<502$ \\
\hline Chromium & $145 \pm 9$ & Benzo(g,h,i)perylene & $<502$ \\
\hline Iron & $8484 \pm 752$ & Benzo(a)pyrene & $<502$ \\
\hline Manganese & $76 \pm 8$ & Chrysene & $4600 \pm 1115$ \\
\hline Molybdenum & $16083 \pm 1239$ & Dibenzo(a,h)anthracene & $<502$ \\
\hline Nickel & $387 \pm 28$ & Phenanthrene & $89553 \pm 6008$ \\
\hline Vanadium & $120 \pm 17$ & Indeno(1,2,3-cd)pyrene & $<502$ \\
\hline Zinc & $307 \pm 50$ & Ethylbenzene & $20517 \pm 1269$ \\
\hline Sulfides & $181002 \pm 1590$ & $m, p$-Xylenes & $34443 \pm 6279$ \\
\hline TPH g/kg. & $240371 \pm 2657$ & $o$-Xylene $\mu \mathrm{g} / \mathrm{kg}$ & $29271 \pm 6157$ \\
\hline
\end{tabular}


were observed during the entire assayed period when the $\mathrm{T} \& \mathrm{~K}$ medium was employed. The reduction in the $\mathrm{pH}$ (Figure 1B) of the cultivation medium is related to an increase in the acidity which, due to the value for the dissociation constant of sulfuric acid, enables values of less than 1.0 to be reached. The decrease in the $\mathrm{pH}$ of the medium is indicative of bacterial activity in the bioleaching system, since an increase or decrease in the $\mathrm{pH}$ is dependent on, respectively, the consumption of acid by the material and/or by the bacteria and the production of acid resulting from biochemical sulfide oxidation reactions (Francisco et al., 2007). Chang et al. (2008) cultivated the bacterial strain $A$. thiooxidans BCRC 15616 and observed that an exponential growth phase began on the fifth day and lasted 10 days, resulting in a decrease in the $\mathrm{pH}$ from 4.5 to 1.4 . Moura et al. (2008) also observed that the growth of sulfur-oxidizing bacteria, in the medium 9K (Silverman and Lundgren, 1959), resulted in an increase in the acidity, but the minimum value of $\mathrm{pH} 1.0$ was reached only after 20 days. This verifies the potential of $A$. thiooxidans $\mathrm{FG}-01$ to produce acids, which favors the leaching of metals from the spent HDS catalyst as a solid residue. Another important factor is that the $T \& K$ medium contains a lower quantity of nutrients, which makes it more economically advantageous than DSMZ, and thus this mineral medium was selected for the subsequent tests.

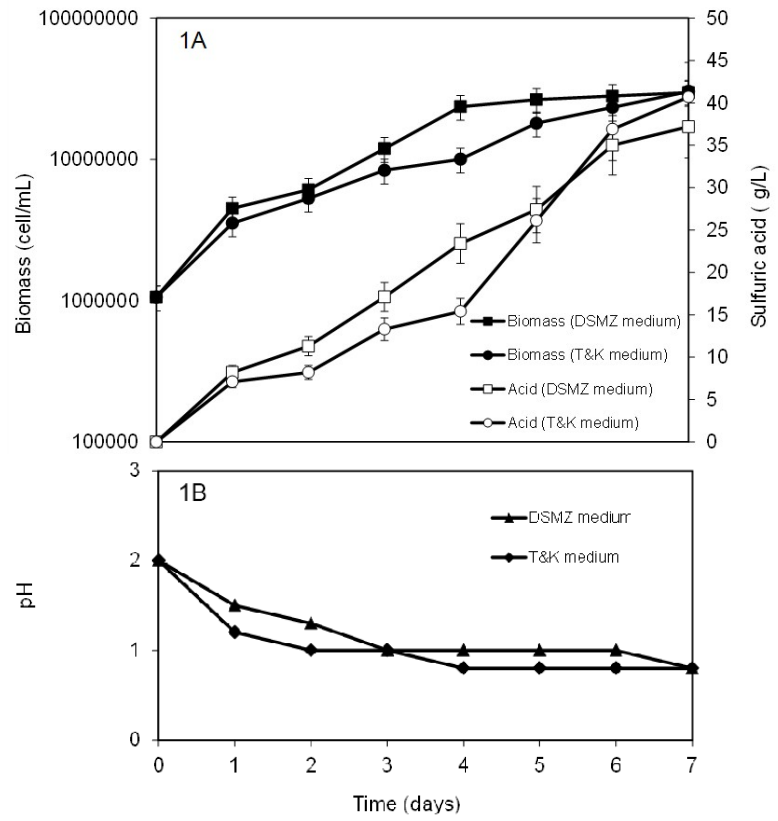

Figure 1: Cultivation of bacterial strain $A$. thiooxidans FG-01 in the DSMZ and T\&K media: (A) Kinetic profiles for the growth and production of sulfuric acid and (B) behavior of the $\mathrm{pH}$.

\section{Effect of the Catalyst Density and $A$. thiooxidans FG-01 Activity}

The pulp density is an important variable which affects the success of the bioprocess. It can influence the oxygen mass transfer from gas to liquid phase, microbial adhesion and the release of toxic chemicals from solids to the solution (Wang et al., 2014). Thus, tests of the effect of the pulp density on the $A$. thiooxidans FG-01 strain as a function of the contact time were carried out. Figure 2 shows the results obtained after 5 days of cultivation in T\&K medium using different catalyst densities ( 5 to $50 \mathrm{~g} / \mathrm{L}$ ). It can be observed that there was only significant bacterial growth, of around one order of magnitude, when the cultivation was carried out in medium containing 5 $\mathrm{g} / \mathrm{L}$ of catalyst, resulting in the production of approximately $29 \mathrm{~g} / \mathrm{L}$ of sulfuric acid. The cell concentration remained almost unaltered, reaching $3.1 \times 10^{6}$ cells $/ \mathrm{mL}$, with a pulp density of $10 \mathrm{~g} / \mathrm{L}$, while slightly lower cell concentrations were observed for the other catalyst densities.

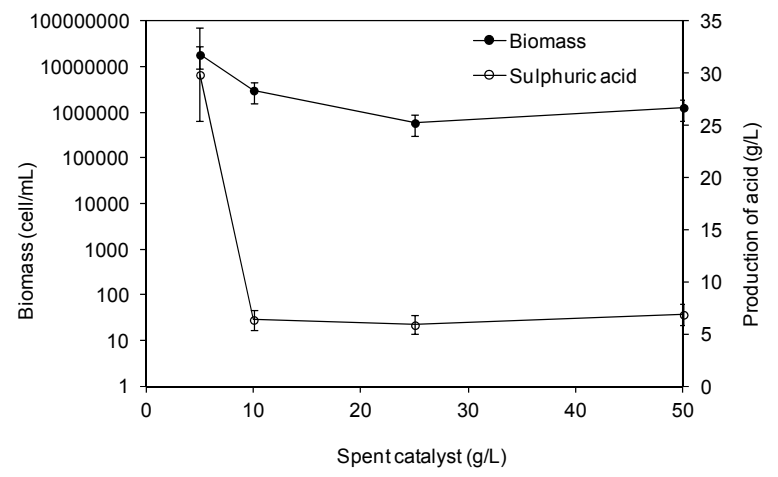

Figure 2: Influence of pulp density on the cell concentration and production of acid (initial average cell concentration of $10^{5}$ cells $/ \mathrm{mL}$ ).

Mishra et al. (2007) carried out studies on the bioleaching of metals by $A$. thiooxidans, with previously adapted cells, and observed cell growth up to a pulp density of $20 \mathrm{~g} / \mathrm{L}$; however, the catalyst used had been submitted to thermal pretreatment $\left(750^{\circ} \mathrm{C}\right.$ for $2 \mathrm{~h}$ ). Thermally or chemically pretreated catalysts were not used in this study and the bacterial strain was not previously adapted to the contaminants (organics or metals). The aim was to reduce the process stages, seeking economic viability for future largerscale (scale up) studies. Another important factor to be considered is that the increase in the pulp density can be limiting in terms of the oxygen transfer from the gaseous to the liquid phase and, consequently, be inappropriate for microbial activity (KIM et al., 
2009). Also, the decrease in the activity can negatively affect the electron transfer mechanism and influence the metal leaching process. In addition to these factors, the oxidation of sulfide due to the microbial activity can increase the recovery efficiency of the metals encapsulated by this form of sulfur. Based on the results, a pulp density of $5 \mathrm{~g} / \mathrm{L}$ was selected for the subsequent tests and it can be concluded that the solubilized metal concentration and the presence of the other contaminants had an important influence on the cell activity and consequently the bioleaching process.

\section{Direct Microbial Leaching}

Of the direct microbial leaching procedures available, two basic approaches are generally applied for the recovery of metals from solid wastes: the production of acid associated with (one-stage batch bioleaching) or not associated with (two-stage batch bioleaching) metal recovery (Coto et al., 2008). Both approaches were investigated in this study. The cell growth and the production of acid in the presence of the spent catalyst, with or without supplementation with elemental sulfur, are shown in Figure 3.

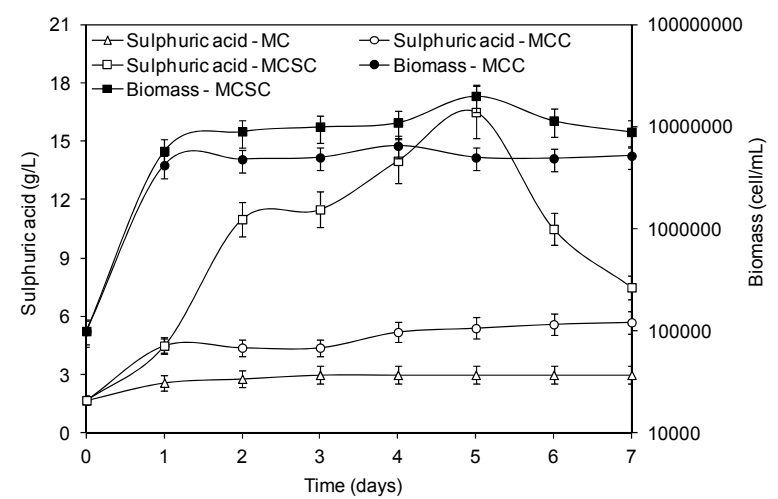

Figure 3: Profiles for growth and sulfuric acid production during the cultivation of $A$. thiooxidans FG01 in: $\mathrm{MC}$ - abiotic control, mineral medium supplemented with spent catalyst $(5 \mathrm{~g} / \mathrm{L}) ; \mathrm{MCC}$ - mineral medium supplemented with spent catalyst and inoculated with cells; and MCSC - mineral medium supplemented with spent catalyst, elemental sulfur and cells.

It can be observed from Figure 3 that the addition of elemental sulfur as an energy source had a positive influence on the cell growth, even though the spent catalyst contains sulfide, another potential energy source for use by the bacteria. This indicates that the catalyst alone was not able to provide the support required for the bacterial growth and that, at this pulp density, the quantity of the energy source present allowed the microbial population to survive. The addition of $\mathrm{S}^{\mathrm{o}}$ (MCSC) resulted in an increase in the cell concentration of one order of magnitude, reaching the maximum value on the fifth day. It can be verified from Figure 3 that the presence of organic contaminants did not inhibit the bacterial growth and that, up to the fifth day of cultivation, the solubilized metals did not affect the cell growth, since the yield and cell productivity were similar to those obtained in the T\&K medium without catalyst (Figure 1A).

The MCSC conditions were the most favorable for the microbial production of acid, which was found to be associated with the cell growth. The maximum sulfuric acid concentration of $16.7 \mathrm{~g} / \mathrm{L}$ was reached on the fifth day. In comparison, under the MCC conditions the acid production was negligible. It was noted that the initial acid concentration in the medium was introduced by the inoculation. Furthermore, the acid production was negligible in the abiotic control, suggesting that, in the absence of cells, oxidative reactions did not occur.

The leaching solutions obtained in the MCC and MCSC tests were analyzed for metals in solution, and the contents were used in the calculation of the percentage recovery from the catalyst, based on their concentrations before the application of the treatment. For comparison purposes, the chemical leaching of the catalyst with commercial sulfuric acid (abiotic control) was also carried out, and the solutions were obtained after the same time interval (Table 2). The data related to the abiotic control medium are not shown since the metal concentrations in the leaching solutions during the period monitored were negligible $(<0.5 \%)$.

It is of interest to note that the solubilization of the metals, in general, increased over time, although the acid production stopped on the fifth day, when it suddenly declined (Figure 3). This could explain the inhibition of the microbial activity since, as previously observed, the culture employed in this study reached its maximum growth around the fifth day of cultivation. However, in the medium without catalyst it was possible to reach around $40 \mathrm{~g} / \mathrm{L}$ of sulfuric acid, while in the presence of metals the maximum acid concentration was much lower (around $17 \mathrm{~g} / \mathrm{L}$ ), which was probably a consequence of the toxicity of the metals in solution toward the bacteria.

Cobalt and copper could not be recovered in significant quantities through the chemical or microbial leaching. The enrichment of the microbial leaching medium with elemental sulfur did not have a strong influence on the recovery of the other metals investigated, as can be noted for Mo and $\mathrm{V}$ with recoveries 
of the order of $37 \%$ and $29 \%$, respectively. In the case of Mo, the chemical leaching was more efficient with a recovery of $65 \%$, while no difference was observed for $\mathrm{V}$ recovery on comparing chemical and microbial leaching. The Ni recovery was considered to be low, particularly compared with the value of approximately $85 \%$ reported by Kim et al (2009), probably due to the differences in terms of the solid matrix, pulp density and bacterial strain employed. Mishra et al. (2008) managed to recover $88.2 \%$ of $\mathrm{Ni}, 93 \%$ of $\mathrm{V}$ and $17.4 \%$ of Mo in a one-stage bioleaching process using spent catalysts previously treated with acetone and dried at $50{ }^{\circ} \mathrm{C}$, triturated to approximately $100 \mu \mathrm{m}$, at a pulp density of $15 \mathrm{~g} / \mathrm{L}$, in a medium containing $\mathrm{S}^{\circ}$, in 7 days. Thus, the $A$. thiooxidans strain FG-01 can be considered as a potential alternative for the leaching of Mo, a valuable metal, avoiding the need for preliminary grinding and/or a thermal or washing process to remove organic compounds from catalyst, which can reduce the cost effectiveness of the industrial bioprocess.

Table 2: Percentage recovery of metals from spent HDS catalyst by chemical leaching $(C L)$ with commercial sulfuric acid and by bioleaching employing MCC (medium, cells and catalyst) or MCSC (medium, cells, $S^{\circ}$ and catalyst), all with $5 \mathrm{~g} / \mathrm{L}$ of catalyst, under incubation conditions of $30{ }^{\circ} \mathrm{C}$ at 150 rpm.

\begin{tabular}{|c|c|r|r|r|}
\hline \multirow{2}{*}{ Element } & Time & \multicolumn{3}{|c|}{ Recovery (\% m/m) } \\
\cline { 3 - 5 } & (days) & CL & MCC & MCSC \\
\hline \multirow{3}{*}{$\mathrm{Al}$} & 1 & $13 \pm 2$ & $13 \pm 3$ & $13 \pm 2$ \\
& 3 & $16 \pm 1$ & $15 \pm 2$ & $17 \pm 2$ \\
& 7 & $27 \pm 5$ & $27 \pm 4$ & $30 \pm 5$ \\
\hline \multirow{3}{*}{$\mathrm{Co}$} & 1 & $1 \pm 1$ & $1 \pm 1$ & $1 \pm 1$ \\
& 3 & $2 \pm 1$ & $2 \pm 1$ & $2 \pm 1$ \\
& 7 & $2 \pm 1$ & $2 \pm 1$ & $2 \pm 1$ \\
\hline \multirow{3}{*}{$\mathrm{Cu}$} & 1 & $1 \pm 1$ & $2 \pm 1$ & $2 \pm 1$ \\
& 3 & $2 \pm 1$ & $2 \pm 1$ & $2 \pm 2$ \\
& 7 & $2 \pm 1$ & $2 \pm 1$ & $2 \pm 1$ \\
\hline \multirow{3}{*}{$\mathrm{Mo}$} & 1 & $15 \pm 3$ & $12 \pm 4$ & $11 \pm 2$ \\
& 3 & $32 \pm 5$ & $21 \pm 3$ & $22 \pm 3$ \\
& 7 & $65 \pm 5$ & $39 \pm 4$ & $37 \pm 3$ \\
\hline \multirow{3}{*}{$\mathrm{Ni}$} & 1 & $4 \pm 1$ & $4 \pm 1$ & $4 \pm 1$ \\
& 3 & $4 \pm 1$ & $4 \pm 2$ & $4 \pm 1$ \\
& 7 & $5 \pm 2$ & $5 \pm 2$ & $5 \pm 2$ \\
\hline \multirow{3}{*}{$\mathrm{V}$} & 1 & $21 \pm 2$ & $21 \pm 1$ & $20 \pm 3$ \\
& 3 & $23 \pm 2$ & $23 \pm 4$ & $25 \pm 4$ \\
& 7 & $27 \pm 3$ & $30 \pm 4$ & $29 \pm 3$ \\
\hline
\end{tabular}

Based on the data obtained, it can be established that the solubilization of metals through microbial action occurs in the following decreasing order, as observed from the recovery obtained from the action of $A$. thiooxidans FG-01: $\mathrm{Mo}>\mathrm{V}=\mathrm{Al}>\mathrm{Ni}>\mathrm{Cu}>$ Co. On comparing the microbial and chemical leach- ing for the process carried out in one-stage, it can be concluded that the bioprocess is equivalent to the chemical process. These results show the potential for the use of this microorganism as an alternative process for the recovery of Mo from the spent catalyst studied. In the present study, the differences in metal removals can be particularly related to their binding forms and sulfuric acid concentration. The biosurfactant action may not be dismissed, although its microbial production was not investigated. Spent catalysts have different metal-binding capacity; therefore, metals can be divided into acid soluble/exchangeable, and reducible/oxidizable or residual fractions (Srichandan et al., 2014b). The exchangeable and reducible fractions are related to weekly adsorbed elements retained on the surface by relatively weak electrostatic attraction. The oxidizable fraction contains the metals involved in complexation with organic matter. At last, the residual fraction comprises metals incorporated into the crystal lattice of minerals. So, comparatively, the metals in the residual fraction are strongly bound, whereas metals in the other fractions bind weakly through electrostatic attraction (Srichandan et al., 2014b).

\section{Indirect Microbial Leaching}

In the set of two-stage bioleaching tests the metal recovery occurred due to the treatment of the catalyst with the leaching solution originating from the previous microorganism growth in the T\&K medium, in the absence of the catalyst. The aim of this stage of the study was to evaluate whether the metabolites, produced during the microbial growth, participated effectively in the solubilization of the metals, as well as to verify if this second approach to the bioprocess is more effective. It is known that the bacteria of the genus Acidithiobacillus can produce tensioactive agents which can aid in the recovery of metals (Schaeffer and Umbreit 1963; Beebe and Umbreit 1971; Fazzini et al., 2011). To allow a comparative analysis, the catalyst was also treated with a solution of commercial sulfuric acid, applying the same ratios of catalyst density/acid concentration in the leaching solutions. The results obtained for the metal concentrations in solution are shown in Table 3.

A multiple comparison of the means for the recovery of the metals revealed that molybdenum had the greatest percentage recovery of the metals tested, regardless of the pulp density. In addition, it was verified that, in the tests carried out with a pulp density of $5 \mathrm{~g} / \mathrm{L}$, the chemical and microbiological treatments provided the same recovery percentage for this element. However, it should be noted that an in- 
crease in the pulp density from 5 to $50 \mathrm{~g} / \mathrm{L}$ led to a reduction in the Mo recovery. Beolchini et al. (2010) reported yields for the microbial leaching of Mo from spent HDS catalysts of below $30 \%$ after 20 days of contact. The results reported herein are consistent with those reported by Mishra et al. (2007), who studied different pulp densities $(5 \mathrm{~g} / \mathrm{L}$ to $50 \mathrm{~g} / \mathrm{L})$ and obtained the maximum value for Mo recovery $(71.1 \%)$ in the tests conducted with $5 \mathrm{~g} / \mathrm{L}$ of catalyst in a two-stage process with 7 days of incubation. For a pulp density of $50 \mathrm{~g} / \mathrm{L}$, a recovery of $21.5 \%$ was observed. Under the same process conditions, Ho et al. (1994) obtained Mo recoveries of $78.6 \%$ to $42.6 \%$ for pulp densities of $5 \mathrm{~g} / \mathrm{L}$ to $50 \mathrm{~g} / \mathrm{L}$.

Table 3: Indirect bioleaching as a function of the pulp density of the crude spent catalyst.

\begin{tabular}{|c|r|r|r|r|}
\hline \multirow{2}{*}{ Element } & \multicolumn{4}{|c|}{ Recovery (\% m/m) } \\
\cline { 2 - 5 } & \multicolumn{2}{|c|}{5 g/L } & \multicolumn{2}{|c|}{50 g/L } \\
\hline & Bioleaching & Leaching & Bioleaching & Leaching \\
$\mathrm{Al}$ & $31 \pm 2^{\mathrm{b}}$ & $27 \pm 2^{\mathrm{b}}$ & $24 \pm 2^{\mathrm{b}}$ & $22 \pm 3^{\mathrm{b}}$ \\
$\mathrm{Co}$ & $0.2 \pm 0.2^{\mathrm{d}}$ & $0.2 \pm 0.1^{\mathrm{d}}$ & $0.2 \pm 0.2^{\mathrm{d}}$ & $0.2 \pm 0.1^{\mathrm{d}}$ \\
$\mathrm{Cu}$ & $1.1 \pm 0.5^{\mathrm{d}}$ & $0.8 \pm 0.4^{\mathrm{d}}$ & $0.2 \pm 0.1^{\mathrm{d}}$ & $0.2 \pm 0.1^{\mathrm{d}}$ \\
$\mathrm{Mo}$ & $55 \pm 6^{\mathrm{a}}$ & $54 \pm 4^{\mathrm{a}}$ & $39 \pm 3^{\mathrm{a}}$ & $41 \pm 4^{\mathrm{a}}$ \\
$\mathrm{Ni}$ & $4 \pm 2^{\mathrm{c}}$ & $4 \pm 1^{\mathrm{c}}$ & $4 \pm 1^{\mathrm{c}}$ & $4 \pm 1^{\mathrm{c}}$ \\
$\mathrm{V}$ & $30 \pm 2^{\mathrm{b}}$ & $28 \pm 2^{\mathrm{b}}$ & $26 \pm 2^{\mathrm{b}}$ & $26 \pm 3^{\mathrm{b}}$ \\
\hline
\end{tabular}

Note: For the same pulp density, the same lowercase letters indicate that the data are not significantly different, according to the Tukey test $(p>$ $0.05)$

It can be verified from the data in Table 2 that, regardless of the pulp density, the same percentages of $\mathrm{V}$ and $\mathrm{Al}$ were removed from the solid matrix. In the case of Al, a similarity was observed between the leaching carried out with acid produced by bacteria and commercial sulfuric acid (confidence level 95\%). Also, an increase in the pulp density from 5 to $50 \mathrm{~g} / \mathrm{L}$ did not affect the solubilization of this element. Some studies have revealed that the bioleaching of $\mathrm{Al}$ can be carried out in cultures of $A$. thiooxidans with a yield of approximately $40 \%$ (Krebs et al., 1997). Other authors have reported that, on applying bioleaching with fungi, it is also possible to recover $\mathrm{Al}$, with around $30 \%$ recovery (Aung and Ting, 2005; Santhiya and Ting, 2005). The solubilization of $\mathrm{V}$ was not influenced by the pulp density or by the type of leaching (chemical or microbial) used. The recovery results are promising since, during the use of catalysts in the HDS process, vanadium complexes are deposited on the catalyst particles and, subsequently, these complexes decompose due to the high temperatures in the reactors (Trujillo et al., 1997). During the regeneration of the catalyst, the water vapor produced from the combustion of coke, deposited on the particles, oxidizes vanadium and the resulting oxide hydrolyzes, forming a volatile species, vanadic acid, which can permeate the inner layers of the catalyst particles, hindering the extraction of vanadium. The literature reports high values for $\mathrm{V}$ recovery $(>90 \%)$, however, for spent catalysts submitted to chemical or thermal pretreatment and with contact times exceeding one week (Mishra et al., 2008; Kim et al., 2009).

In the case of $\mathrm{Ni}$, no statistically significant difference was observed on employing chemical or microbial leaching, regardless of the pulp density studied. Pradhan et al. (2009), Beolchini et al. (2010), Noori et al. 2014, and Bharadwaj and Ting (2013) reported values for Ni recovery of over $50 \%$ for pretreated HDS catalysts. Thus, the bacterial strain $A$. thiooxidans FG-01 is not considered to be promising for the recovery of this element. The values for the recovery of $\mathrm{Co}$ and $\mathrm{Cu}$ were also low $(<2 \%)$. For these elements it was not possible to verify the influence of the type of leaching used (chemical or microbial), but the influence of the pulp density was verified in the case of $\mathrm{Cu}$. In the literature, most publications report the recovery of $\mathrm{Co}$ from pretreated residues with the use of commercial solvents. For instance, Hubred (1984) extracted $45 \%$ of the Co present in a spent catalyst using chemical treatment with ammonium sulfate or carbonate, with $\mathrm{pH}$ values between 9.5 and 11 , at high temperature $\left(85-95^{\circ} \mathrm{C}\right)$. Gómez et al. (1999) obtained a maximum solubilization of $25 \%$ for copper in the bioleaching of an ore originating from Spain, with high concentrations of sulfide, using Acidithiobacillus ferrooxidans at a pulp density of 5\%, at pH 2.0 after 15 days. Xia et al. (2008) reported a differentiated bioleaching of chalcopyrite, using $A$. ferrooxidans, adapted or not adapted to $\mathrm{Cu}$. After 21 days of the test, employing a pulp density of $5 \%$, the recoveries were $47.5 \%$ and $39.5 \%$, respectively.

Based on a comparison of the data in Tables 2 and 3 it can be verified that, for a pulp density of $5 \mathrm{~g} / \mathrm{L}$, the two-stage bioleaching led to higher recovery percentages for Mo, V and Al. In the case of the other elements analyzed, no difference was observed regarding the type of recovery process applied. However, considering the mass recovery data, it can be verified that the two-stage bioprocess, with a pulp density of $50 \mathrm{~g} / \mathrm{L}$, provided higher quantities of the leached metals analyzed $(31.3 \mathrm{~g} / \mathrm{L} \mathrm{Al}, 54.6 \mathrm{~g} / \mathrm{L}$ Mo and $30.4 \mathrm{~g} / \mathrm{L} \mathrm{Mo}$ ), this being the best condition tested.

The SEM micrographs in Figure 4 show the superficial aspect of the spent HDS catalyst samples before (Figure 4A) and after treatment with commercial sulfuric acid solutions (Figure 4B) or microbial 


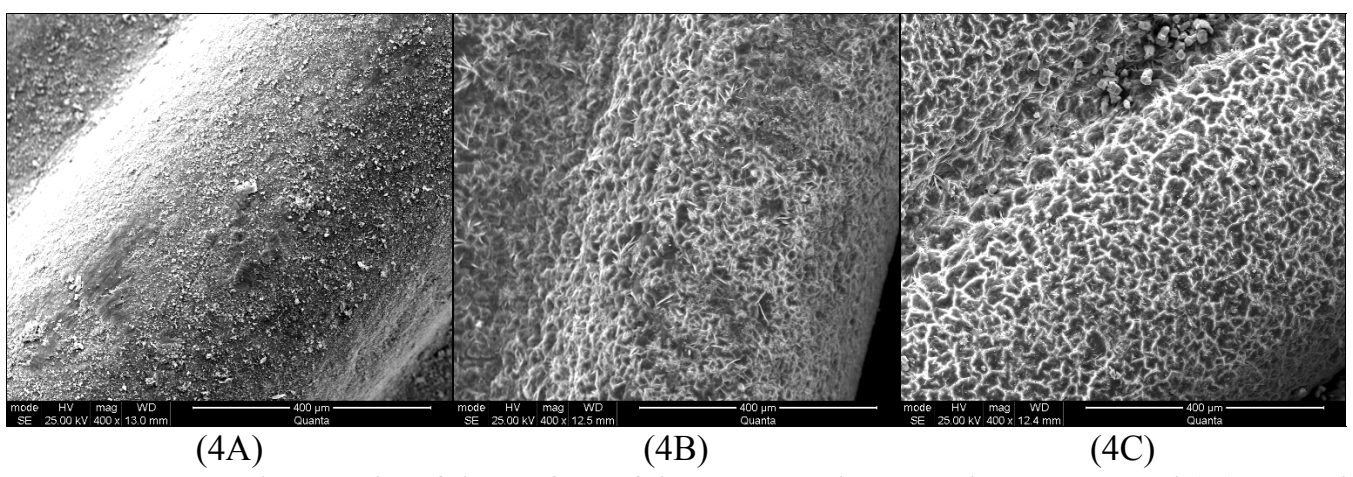

Figure 4: SEM micrographs of the surface of the spent catalyst samples: non-treated (A), treated with commercial sulfuric acid (CSA) (B) and treated with acid produced by $A$. thiooxidans (C).

leaching (Figure 4C), for the recovery of metals. The leached catalyst samples show a thick surface layer with an aspect which differs considerably from that of the surface of the material observed before the treatment.

Scanning electron microscopy (SEM) coupled to energy dispersive X-ray spectroscopy (EDS) was carried out to examine the surface aspect of the HDS spent catalyst before and after the chemical or microbiological leaching tests. Changes in concentrations of chemical elements on the surfaces of the catalyst samples were also investigated in this analysis. The EDS peaks for the treated catalysts, regardless of the solution employed, showed similar profiles. However, the spectrum for the catalyst prior to the treatment differed from those of the treated samples, demonstrating the efficiency of the process. The values corresponding to the main elemental constituents of the layer adhered to the surface of the catalyst are shown in Table 4.

Table 4: Concentration of metals in samples of the spent HDS catalyst obtained by EDS before and after chemical (CL) or microbial (ML) leaching.

\begin{tabular}{|l|c|c|c|}
\hline \multirow{2}{*}{ Element } & \multicolumn{3}{|c|}{ Concentration (\% m/m) } \\
\cline { 2 - 4 } & $\begin{array}{c}\text { Spent } \\
\text { catalyst }\end{array}$ & CL & ML \\
\hline $\mathrm{Al}$ & 10.06 & 7.90 & 8.18 \\
$\mathrm{Co}$ & 0.07 & 0.06 & 0.05 \\
$\mathrm{Cu}$ & 0.15 & 0.14 & 0.12 \\
$\mathrm{Mo}$ & 7.32 & 1.82 & 1.49 \\
$\mathrm{Ni}$ & 2.14 & 1.48 & 1.06 \\
$\mathrm{~V}$ & 0.02 & 0.02 & 0.02 \\
$\mathrm{Fe}$ & 7.00 & 0.08 & 0.05 \\
$\mathrm{O}$ & 21.01 & 52.83 & 64.51 \\
\hline
\end{tabular}

The increase in the oxygen concentration of the samples treated by direct microbial bioleaching demonstrated the deposition of organic material. Based on a comparison of the data in Tables 2, 3 and 4 , it can be concluded that preferential dissolution of the metals adhered to the catalyst surface occurred, since the EDS analysis quantifies the elements of the superficial layer and cannot detect elements deposited in the micropores of the catalyst. Since the AAS technique is preceded by the acid dissolution of the material, the differences between the quantities of metals recovered is explained.

\section{CONCLUSIONS}

The bacterial strain Acidithiobacillus thiooxidans FG-01 was used successfully to recover metals of aggregated value from a spent HDS catalyst $(\mathrm{CoMo} /$ $\mathrm{Al}_{2} \mathrm{O}_{3}$ ) without chemical, thermal or physical pretreatment. The two-stage bioprocess carried out with a pulp density of $50 \mathrm{~g} / \mathrm{L}$ yielded the highest quantities of leached metals (Al, V and Mo) and these were considered to be the best conditions tested. It was not possible to recover $\mathrm{Co}, \mathrm{Cu}$ or $\mathrm{Ni}(<5 \%)$ under any of the conditions tested. The hazardous solid waste investigated in this study appears to represent a low cost material for the recovery of valuable metals. The application of this process could reduce the need for mining activities and thus the degradation of new areas, thereby contributing to environmental sustainability.

\section{NOMENCLATURE}

\section{AAS Atomic absorption spectrometry \\ CL Chemical leaching \\ CSA Commercial sulfuric acid}

DSMZ Deutsche sammlung von mikroorganismen und zellkulturen

EDS Energy dispersive X-ray spectroscopy

FID Flame ionization detector

HDS Hydrodesulfurization

LOD Limit of detection 
MC Mineral medium supplemented with spent catalyst

MCC Mineral medium supplemented with spent catalyst and inoculated with cells

MCSC Mineral medium supplemented with spent catalyst, elemental sulfur and cells

MC Abiotic control

ML Microbial leaching

PAHs Polycyclic aromatic hydrocarbons

SEM Scanning electron microscopy

T\&K Tuovinen and Kelly medium

\section{REFERENCES}

Asghari, I., Mousavi, S. M., Amiri, F., Tavassoli, S., Bioleaching of spent refinery catalysts: A review. Journal of Industrial and Engineering Chemistry, 19, 1069-1081 (2013).

Aung, K. M. M., Ting, Y., Bioleaching of spent fluid catalytic cracking catalyst using Aspergillus niger. Journal of Biotechnology, 116, 159-170 (2005).

Beebe, J. L., Umbreit, W. W., Extracellular lipid of Thiobacillus thiooxidans. Journal of Bacteriology, 108, 612-614 (1971).

Beolchini, F., Fontia, V., Ferella, F., Vegliò, F., Metal recovery from spent refinery catalysts by means of biotechnological strategies. Journal of Hazardous Materials, 178, 529-534 (2010).

Bharadwaj, A., Ting, Y-P., Bioleaching of spent hydrotreating catalyst by acidophilic thermophile Acidianus brierleyi: Leaching mechanism and effect of decoking. Bioresource Technology, 130, 673-680 (2013).

Chang, J. H., Hocheng, H., Chang, H. Y., Shih, A., Metal removal rate of Thiobacillus thiooxidans without pre-secreted metabolite. Journal of Materials Processing Technology, 20(1), 560-564 (2008).

Chen, S-Y., Chen, W-H., Thermophilic bioleaching of heavy metals from waste sludge using response surface methodology. Journal of Environmental Science and Health, Part A, 48(9), 1094-1104 (2013).

Coto, A., Galizia, F., Hernández, I., Marrero, J., Donati, E., Cobalt and nickel recoveries from laterite tailings by organic and inorganic bio-acids. Hydrometallurgy, 94, 18-22 (2008).

Dhar, G. M., Srinivas, B. N., Rana M. S., Kumar, M., Maity, S. K., Mixed oxide supported hydrodesulfurization catalysts-a review. Catalysis Today, 86, 45-60 (2003).

Fazzini, R. A. B., Levican, G., Parada, P., Acidithiobacillus thiooxidans secretome containing a newly described lipoprotein Licanantase enhances chalcopyrite bioleaching rate. Applied Microbiology and Biotechnology, 89, 771-780 (2011).

Felegari, Z. N., Haghi, N. B., Amoabediny, G., Mousavi, S. M., Torkmahalleh, A. M., An optimized integrated process for the bioleaching of a spent refinery processing catalysts. International Journal Environmental Research, 8(3), 621-634 (2014).

Francisco Jr, W. E., Bevilaqua, D., Garcia Jr, O., Estudo da dissolução oxidativa microbiológica de uma complexa amostra mineral contendo pirita $\left(\mathrm{FeS}_{2}\right)$, pirrotita $\left(\mathrm{Fe}_{1}-\mathrm{xS}\right)$ e molibdenita $\left(\mathrm{MoS}_{2}\right)$. Química Nova, 30(5), 1095-1099 (2007). (In Portuguese).

Garcia Jr, O., Isolation and purification of Thiobacillus ferrooxidans and Thiobacillus thiioxidans from some coal and uranium mines of Brazil. Revista de Microbiologia, 22, 1-6 (1991).

Gary, J. H., Handwerk, G. E., Kaise, M. J., Petroleum Refining: Technology and Economics. CRC Press, Boca Raton (2007).

Gómez, C., Blázquez, M. L., Ballester, A., Bioleaching of a Spanish complex sulphide ore bulk concentrate. Minerals Engineering, 12(1), 93-106 (1999).

Han, W., Yuan, P., Fan, Y., Shi, G., Liu, H., Baic, D., Bao, X., Preparation of supported hydrodesulfurization catalysts with enhanced performance using Mo-based inorganic-organic hybrid nanocrystals as a superior precursor. Journal of Material Chemistry, 22, 25340-25353 (2012).

Ho, E. M., Kyle, J., Lallenec, S., Muir, D. M., Parker, A. J., Recovery of vanadium from spent catalysts and alumina residues. Proc. Hydrometallurgy, Londres, Chapman and Hall, p. 1105-1121 (1994).

Hubred, G. L., Leaching nickel, cobalt, molybdenum, tungsten and vanadium from spent hydroprocessing catalysts. American Patent $\mathrm{n}^{\mathrm{o}}$ 4.514.368 (1984).

Jadhav, U. U. and Hocheng, H., A review of recovery of metals from industrial waste. Journal of Achievements in Materials and Manufacturing Engineering, 54(2), 159-167 (2012).

Kim, D. J., Mishra, D., Ahn, J., Chaudhury, G. R., Ralph, D. E., A novel process to treat spent petroleum catalyst using sulfur-oxidizing lithotrophs. Journal of Environmental Science and Health, Part A, 44, 1585-1591 (2009).

Krebs, W., Brombacher, C., Bosshard, P. P., Bachofen, R., Brandl, H., Microbial recovery of metals from solids. FEMS Microbiology Reviews, 20, 605-617 (1997).

Marafi, M. and Stanislaus, A., Spent hydroprocessing catalyst management: A review Part II. Advances in metal recovery and safe disposal methods. 
Resources, Conservation and Recycling, 53, 1-26 (2008).

Marafi, M. and Stanislaus, A., Waste catalyst utilization: Extraction of valuable metals from spent hydroprocessing catalysts by ultrasonic-assisted leaching with acids. Industrial and Engineering Chemistry Research, 50, 9495-9501 (2001).

Mishra, D., Kim, D. J., Ralph, D. E., Ahn, J. G., Rhee, Y. H., Bioleaching of spent hydro-processing catalyst using acidophilic bacteria and its kinetics aspect. Journal of Hazardous Materials, 152, 1082-1091 (2008).

Mishra, D., Kim, D. J., Ralph, D. E., Ahn, J. G., Rhee, Y. H., Bioleaching of vanadium rich spent refinery catalysts using sulfur oxidizing lithotrophs. Hydrometallurgy, 88, 202-209 (2007).

Moura, M. J., Ribeiro, B., Sousa, J., Costa-Ferreira M., Leaching of petroleum refinery ash by acidophilic sulfur-oxidizing microbial cultures. Bioresource Technology, 99, 8840-8843 (2008).

Mousavi, S. M., Yaghmaei, S., Vossoughi, M., Roostaazad, R., Jafari, A., Ebrahimi, M., Chabok, O. H., Turunen, I., The effects of $\mathrm{Fe}(\mathrm{II})$ and $\mathrm{Fe}(\mathrm{III})$ concentration and initial $\mathrm{pH}$ on microbial leaching of low-grade sphalerite ore in a column reactor. Bioresource Technology, 99, 2840-2845 (2008).

Noori, F. Z., Nematdoust, H. B., Amoabediny, G., Mousavi, S. M., Amouei T. M., An optimized integrated process for the bioleaching of a spent refinery processing catalysts. International Journal Environmental Research, 8, 621-634 (2014).

Plumb, J. J., Mcsweeney, N. J., Franzmann, P. D., Growth and activity of pure and mixed bioleaching strains on low grade chalcopyrite ore. Minerals Engineering, 21, 93-99 (2008).

Pradhan, D., Mishra, D., Kim, D. J., Chaudhury, G. R., Lee, S. W., Dissolution kinetics of spent petroleum catalyst using two different acidophiles. Hydrometallurgy, 99, 157-162 (2009).

Sahu, K. K., Agrawal, A., Mishra, D., Hazardous waste to materials: Recovery of molybdenum and vanadium from acidic leach liquor of spent hydroprocessing catalyst using alamine 308. Journal of Environmental Management, 125, 68-73 (2013).

Santhiya, D., Ting, Y., Bioleaching of spent refinery processing catalyst using Aspergillus niger with high-yield oxalic acid. Journal of Biotechnology, 116, 171-184 (2005).

Schaeffer, W. I., Umbreit, W. W., Phosphotidylinositol as a wetting agent in sulfur oxidation by Thiobacillus thiooxidans. Journal of Bacteriology, 85, 492-493 (1963).

Silverman, M. P., Lundgren, D. G., Studies on the chemoautotropic iron bacterium Ferrobacillus ferroxidans. I. An improved medium and a harvesting procedure for securing high cell yields. Journal Bacteriology, 77, 642-647 (1959).

Srichandan, H., Pathak, A., Kim, D. J., Lee, S-W., Optimization of two-step bioleaching of spent petroleum refinery catalyst by Acidithiobacillus thiooxidans using response surface methodology. Journal of Environmental Science and Health, Part A: Toxic/Hazardous Substances and Environmental Engineering, 49(14), 1740-1753 (2014a).

Srichandan, H., Singh, S., Pathak, A., Kim, D. J., Lee, S-W., Heyes, G., Bioleaching of metals from spent refinery petroleum catalyst using moderately thermophilic bacteria: Effect of particle size. Journal Environmental Science and Health, Part A, 49(7), p. 807-818 (2014b).

Thosar, A., Satpathy, P., Nathiya, T., Rajan, A. P., Biomining: A revolutionizing technology for a safer and greener environment. International Journal of Recent Scientific Research, 5(9), 16241632 (2014).

Trujillo, C. A., Uribe, U. N., Knops-Gerrits, P., Oviedo, L. A., Jacobs, P. A., The mechanism of zeolite $\mathrm{Y}$ destruction by steam in the presence of vanadium. Journal of Catalysis, 168, 1-15 (1997).

Tuovinen, O. H., Kelly, D. P., Studies on the growth of Thiobacillus ferroxidans. I. Use of membrane filters and ferrous iron agar to determine viable number and comparison with 14CO2- fixation and iron oxidation as measures of growth. Archives of Microbiology, 88, 285-298 (1973).

USEPA, United States Environmental Protection Agency 1980. Procedures for laboratory analysis of surface/bulk dust loading samples. $<$ http://www. epa.gov/ttnchie1/ap42/appendix/app-c2.pdf> (Accessed: December 20, 2011).

USEPA, United States Environmental Protection Agency 1995. Samplers and sampling procedures for hazardous waste streams. $<$ http://nepis.epa.gov/ Exe/ZyPURL.cgi?Dockey=30000APW.txt $>$ (Accessed: December 20, 2011).

Wang, Y., Su, L., Zeng, W., Wan, L. Chen, Z., Zhang, L., Qiu, G., Chen, X. Zhou, H., Effect of pulp density on planktonic and attached community dynamics during bioleaching of chalcopyrite by a moderately thermophilic microbial culture under uncontrolled conditions. Minerals Engineering, 61, 66-72 (2014).

Xia, L., Xinxing, L., Zeng, J., Yin, C., Gao, J., Liu, J., Mechanism of enhanced bioleaching efficiency of Acidithiobacillus ferrooxidans after adaption with chalcopyrite. Hydrometallurgy, 92, 95-101 (2008). 